\title{
National Movement of Mental Revolution in Developing Character Education of Indonesian Generation
}

\author{
Saiful Saiful*, M. Nasir Basyah \\ State ideology and civic education, the faculty of teacher \\ training and education \\ Universitas Syiah Kuala \\ Aceh, Indonesia \\ *saiful_usman@unsyiah.ac.id
}

\author{
Akhyar Akhyar \\ State ideology and civic education, the faculty of teacher \\ training and education \\ Universitas Abulyatama \\ Aceh, Indonesia
}

\begin{abstract}
The National Movement of the Mental Revolution (GNRM) as mandated by the President of the Republic of Indonesia (Ir. Joko Widodo) on the official speech at the Regional Representative Council on 14 August 2015. The National Movement of the Mental Revolution becomes a new life movement which is capable to change the way of thinking, work and attitude and behavior of better Indonesian citizens based on the values of State Ideology (Pancasila) and the 1945 Constitution of the State of the Republic of Indonesia. The National Movement of the Mental Revolution becomes a breakthrough movement that obstructs the way of thinking, the workings and a lifeoriented way of life for a sovereign, self-reliant nation and state in developing future Indonesia. This study is the result of FGD (Focus Group Discussion) with community leaders in Aceh, involving Academian/education figures, religious leaders, cultural figures/artists, youth leaders, women figures, political figures/representatives of political parties, dissident figures, media figures/press, and netizens. The National Movement of the Mental Revolution contains five movements, namely: The Movement of Serving Indonesia, the Movement of Clean Indonesia, the Movement of Orderly Movement, the Movement of Independent Indonesia, and the United Indonesia Movement. However, in this FGD only discussed three movements, namely: Indonesian Movement, Serving Indonesia Movement, Clean Movement, and Indonesia Orderly. FGD results show that: First, the leaders of the people of Aceh strongly supports the mandate of the President of the Republic of Indonesia Ir. Joko Widodo on the National Movement of the Mental Revolution, so that with the National Movement of Mental Revolution, it would be able to realize Indonesia that is able to serve the people well, a cleaner Indonesia, and a more orderly Indonesia. Secondly, the people of Aceh expect the National Movement of Mental Revolution to become a movement that is able to develop character education of the young generation of Indonesia in the future who have knowledge, expertise, and high morality. In accordance with the values contained in State Ideology (Pancasila), with integrated value of divinity, humanity, unity, democracy, and justice in various aspects of the life of nation and state.
\end{abstract}

Keywords-national movement of mental revolution; character education; young generation of Indonesia

\section{INTRODUCTION}

Character education is a very important part to be continually developed at every level of education in Indonesia, so as to form the character of the personality of the Indonesian young generation intact. The dynamics of the life of the Indonesian young generation from time to time continue to change, many of which evolve to positive sides such as the latest technological discoveries. However, the development to the negative direction is also unavoidable, such as drug abuse, free sex, sexual deviation, and other negative behaviors, which are contrary to the values of Pancasila (the State Ideology).

The young generation's negative behaviors are likely to occur due to many factors. The young generation of Indonesia at the present time seems no longer able to distinguish between right and wrong, and good and bad. Man acts in accordance with his will for the sake of self and group interests, regardless of others. They do not realize that the actions taken will inflict harm on others. The moral crisis is essentially the same as the humanitarian crisis.

If the problem does not get special, proper attention and is not dealt with supposedly, it is likely that the character of the young generation in the future will be slumped and collapsed.

\section{METHOD}

This study is the result of FGD (Focus Group Discussion) with community leaders in Aceh, involving academicians/ education figures, religious leaders, cultural figures/artists, youth leaders, women figures, political figures/representatives of political parties, disability figures, media figures/press, and netizens.

\section{RESUlT AND DisCUSSION}

\section{A. The National Movement of Mental Revolution (GNRM)}

The idea of mental revolution has long been echoed by Indonesia's first president, Ir. Soekarno. This idea was mentioned by Soekarno in a state speech commemorating the 
Independence Day of the Republic of Indonesia, August 17, 1957. President Soekarno then said that mental revolution was like a new life movement to galvanize Indonesians into new human beings, white hearted, steel-bound, eagle-spirited, having the spirit of fire [1].

President Soekarno's remarks in the state speech on 17 August 1957 stirred the spirit of the Indonesian people in continuing their physical development towards mental development to achieve a just and prosperous society. At that time, development challenges faced by the nation included large numbers of poor people, low quality of education, vulnerable social conditions, lagging economies, unstable politics and security, weak leadership, abuses of state property throughout the institutions, and the life gap between the poor and the rich being very wide. Bung Karno invited all components of the nation to jointly implement the mental revolution as a strategy to build sovereign politics, independent economy, and personality in culture. All to reach a just and prosperous society that is the goal of the Indonesian nation [2].

After a long time, the idea of the National Movement of the Mental Revolution (GNRM) was re-mandated by President Joko Widodo in a state speech at the Regional Representative Council on August 14, 2015 [2]. The National Movement of the Mental Revolution presented by President Joko Widodo has widely been accepted by the people of Indonesia, including in Aceh. This means the people understand that the mental or character of the Indonesian nation is experiencing a crisis, and thus it needs to be overcome immediately. Improving the mentality and character of the nation requires a revolutionary action. The revolutionary action must be in a joint movement.

As a movement, the involvement of various components of society is the key to success. The components of the nation such as academicians, religious leaders, cultural figures, artists, youth leaders, women figures, political figures/representatives of political parties, disability figures, media figures/press, netizens, and others.

It must be admitted that the movement of the mental revolution is a concept that has now developed into a mentality for the Indonesian people. The mental revolution includes mental characteristics and capacities, ways and capacities of thinking, feeling and acting, and inner mental activities. Mentality is closely related to character. To shape a strong character, one needs to undergo a series of learning, training and modeling processes. Thus, social and physical environments play a role in shaping individual character [2].

The efforts undertaken by the government in laying the foundations for the nation's character development have in some ways succeeded. The people have realized that $s /$ he is a citizen of a country, namely the Republic of Indonesia which is independent and sovereign. Indonesia as a country founded on the former territory of countries that prior to the arrival of the Dutch were sovereign states. Without realizing this, it would be difficult to unite the Indonesian people. To overcome this, an historical approach to ethnic identity and ethnicity is considered crucial. In this case it is defined as an autoidentification and sense of belonging to a wider group of kinship or network of people who know each other [3].
For example, in order to understand the Diversity to realize Indonesia the Great, surely it is not just that we are able to understand tolerance, but how to change our perspective of complete Indonesian as a whole is much more important. The implementation of the values of life of society, nation and state consistently in an effort to overcome the current, various problems of the nation would require the awareness and commitment of all the people of Indonesia in stabilizing the spirit of national unity. It can be achieved if the people of Indonesia are able to live in the diversity managed well.

Bhinneka Tunggal Ika is a pledge to unite in order to establish the Unitary State of the Republic of Indonesia, the ideals of building a united Indonesian nation, and the expression of a sense of unity that comes from diversity. Pancasila, the 1945 Constitution of the State of the Republic of Indonesia, the Unitary State of the Republic of Indonesia and Bhinneka Tunggal Ika are the basic and principal capital in building a diverse nation.

\section{B. Five National Movements of Mental Revolution}

The Mental Revolution Movement currently being enforced by the government is a real and advanced action in an effort to improve the character of its citizens in general, especially the character of the younger generation. In line with the government program, education through State Ideology and Citizenship Education material has an important meaning in creating a good young generation that is able to support the nation and state. The effort of citizenship of individuals or persons living in a country is a fundamental duty of the state. The concept of good citizen is obviously very dependent of the views of life and political system of the country concerned [4].

The National Movement of the Mental Revolution includes five social movements: 1) the Movement of Indonesia Serving, 2) the Movement of Clean Indonesia, 3) the Movement of Orderly Indonesia, 4) the Movement of Indonesia SelfSupporting, and 5) the Movement of United Indonesia. In the GNRM Facilitator Training Module [2], it is stated that the Movement of Indonesia Serving is a movement undertaken to improve public services of the state civil apparatus which can be felt directly by the community. The Movement of Indonesia Serving seeks to change the mindset/paradigm of public services management from initially oriented to "government as provider" to services oriented to "the needs of society as user". The Movement of Indonesia Serving is a movement that departs from the problems of the Indonesian people in the aspect of public services. Public services in Indonesia are considered still unable to provide satisfactory services to the community, so that the people demand the betterment of services quality provided by the government. Therefore, with the Movement of Indonesia Serving it is expected there is improvement of public services at every institution. The Movement of Indonesia Serving also strives to control and prevent the occurrence of discrepancies and irregularities in the process of providing services to the community.

The Movement of Indonesia Serving will eventually produce the SOP of Prime Public Services which includes the system, that is, public services conducted to the public must be clear, easy, and have openness related to service procedures, 
and every public service has a definite deadline in responding to the community. Public services must also be based on the work ethic principle and have a standard in serving the community. Finally, public services should create synergies to provide material for service provision and provide a system in order for people to give feedback for the public service received. The Movement of Indonesia Serving has the target beneficiaries, i.e. bureaucrats and all Indonesians [2].

Furthermore, the Movement of Clean Indonesia is an act of change of mentality and behavior of the Indonesian people in handling and management of garbage not yet reflecting the culture of cleanliness, such as littering or disposing of garbage not in place, household garbage unsorted between organic and inorganic waste, and the bureaucrat is considered still halfhearted in handling the problem of garbage is a concrete example that the culture of cleanliness is not yet part of the Indonesian people. With the implementation of the Movement of Clean Indonesia, it is expected that cleanliness becomes a culture and it will change the behavior and mentality of the society for a clean environment such as throwing garbage in place, sorting organic and inorganic household waste, and the bureaucrats can handle the cleanliness problem with sincerity. The Movement of Clean Indonesia has two focuses. The first focus is on the community through the waste bank program in the hope that the community have knowledge about clean environment, waste management, waste bank and economic value, so that afterwards, the community is expected to participate in waste management and processing. However, the campaign and socialization to the public should be first carried out [2].

Moreover, the Movement of Orderly Indonesia is one of the movements in the GNRM program to change the behavior of the Indonesian people to be more orderly, especially orderly in using public space, orderly in traffic, and orderly in queuing. One of the problems faced by the Indonesians today is the lack of awareness to behave orderly such as orderly in public space, orderly in traffic, and orderly in queuing. Orderliness is an orderly condition in which the society obeys the prevailing rules. Therefore, through this program orderliness in Indonesia is expected to be realized [2].

The Movement of Indonesia Self-Supporting is a movement of the State Organizers and the public to realize creative, innovative, and high-performing behavior to realize self-supporting in the fields of food, energy and technology in facing regional and global competition. And the Movement of United Indonesia is the movement of the State Organizers and the public to realize mutual respect and mutual cooperation to strengthen national identity and character based on the 4 (four) pillars of nationality, namely Pancasila (State Ideology), 1945 Constitution of the Republic of Indonesia, Bhinneka Tunggal Ika, and The Unitary State of the Republic of Indonesia [2].

However, of the five action movements of the National Movement of the Mental Revolution, only three programs were implemented in 2016, namely the Movement of Indonesia Serving, the Movement of Clean Indonesia, and the Movement of Orderly Indonesia. Meanwhile, the Movement of Indonesia Self-Supporting and the Movement of United Indonesia will be realized in the action program of the National Movement of the Revolution Mental in 2017

\section{Character Education}

Character education is something which should be carried out. This is because character education is an effort in passing values to the younger generation, a process and at every level of education. If we refer to the Law of the National Education System (Sisdiknas) No. 20 of 2003 in article 3 it is stated that: "National education functions to develop the ability and shape the character and civilization of dignified nation in order to educate the nation's life, aims to the development of the potential of students to become human beings who believe and who have piety towards God the Almighty and have noble moral, who are healthy, knowledgeable, capable, creative, independent, and become a democratic and responsible citizen" then we can understand that the main goal of education is to form a faithful and noble man."

The above explanation indicates that the education organized in our country is still not in accordance with the expectations set forth in the law. Therefore, it is important that character education should be implemented in the program of activities both in the curricular and co-curricular programs as well as the extracurricular ones. Character education is an effort in educating the younger generation of Indonesia towards the better, so that the younger generation of Indonesia in the future can contribute positively to the nation and country. The values of character implanted to the young generation of Indonesia are universal ones. In addition, Kamaruddin explained that "character education teaches habitual ways of thinking and behaviors that help individuals to live and work together as a family, community, and state and help them to make decisions that can be accounted for" [5].

Based on the grand design developed by The Ministry of National Education, psychologically and socially, the formation of character in an individual is a function of all human potential in the context of lifelong cultural social interaction. The configuration of characters in the context of the totality of psychological and socio-cultural processes can be grouped into: (1) spiritual and emotional development, (2) intellectual development, (3) physical and kinesthetic development, and (4) affective and creativity development.

Experts have proposed various theories about moral education. Character has the similarities with the moral where morals, norms or character are directly driven by the brain [6]. Bajovic, Rizzo, and Engemann added that "character is borne out of moral elements, thus both character and morality should be accepted as interrelated" [7]. In this case, among the various theories which have developed, there are six theories which are used widely, namely: rational development approach, consideration approach, value clarification approach, cognitive moral development approach, and social behavior approach. Unlike the classification, various theories that develop into three, namely: cognitive approach, affective approach, and behavioral approach. The classification is based on three elements of morality, which usually become the foundation of psychology studies, namely: behavior, cognition, and affection. 
Based on the above discussion it can be asserted that character education is a systematically designed and executed effort to help students understand the values of human behaviors related to God the Almighty, self, fellow human being, environment, and nationality embodied in mind, attitudes, feelings, words, and deeds based on religious norms, law, etiquette, culture, and customs.

The Task Force of the Mental Revolution must be the driving force of the National Movement of the Mental Revolution and the companion of the National Movement of the Mental Revolution Program, which has networks from national to provincial, district/city and even village level. The Task Force of the Mental Revolution is expected to raise the active participation of the agents of change in all aspects of the people's life. Thus the Task Force of Mental Revolution involves various layers and components of the Indonesians formed from the central to the village level, so that the GNRM is really in direct contact with the people.

The responses of the Aceh community figures towards the Movement of Indonesia Serving (GIM) indicate that so far the community has been provided with still less optimal services by public service providers (officers). For example, the officers rarely smile during providing the service, so people feel restless and afraid to get something from the officer; there are officers having less discipline, coming late and going home early; there are officers who seldom answer greetings, so that people feel afraid to ask something to the officer.

In another case, the public is still faced with timeconsuming services concerning letter issuance; for example, for the issuing of land certificates, officers in charge still hold the slogan that if something can be slowed down why then it should be speeded up. The problem is even made worse by illegal charges. Therefore, the Acehnese community leaders prioritize action to officers in order to provide services with smile, easy-to-greet, and not collect illegal charges from the public for any reason. The action of the Movement of Indonesia Serving should be implemented in all government institutions in Aceh.

Regarding the Movement of Clean Indonesia (GIB), the community leaders said that the crucial problems at the moment are: 1) the problem of waste; it is expected that there are garbage bins placed in locations easily reachable by the community. Then, the community is expected to dispose of garbage in the place that has been provided. 2) It is expected that the government will provide bins, not only those intended for organic and inorganic waste, but also those in the form of net as a place to collect mineral water and paper waste. 3) In order to implement the movement of cleanliness both at school and in the village, contests are encouraged to be carried out on a regular basis to select clean schools and villages by awarding rewards or prizes. 4) It is necessary to have schools and villages which can be an example for other schools and villages on hygiene maintenance. 5) Revitalization of clean Friday movement, whether implemented in schools, offices or villages. 6) Provision of garbage bins at the bus stop, so that people can dispose of garbage in the place that has been provided.

According to the community leaders the forms of action that must be carried out are as follows: 1) Target School, to become Clean School; 2) Target Village, to become Clean Village. With the success of these two action programs, it can be an exemplary example for schools and other villages throughout Indonesia, especially in Aceh.

The community leaders of Aceh hope that the Movement of Orderly Indonesia (GIT) becomes one of the movements given special attention, since the issue of order is one that is not easily solved, for example, not queuing, random parking of vehicles, using the cellular phone when riding or driving vehicles, violating traffic signs, and other violations. Thus, the community leaders of Aceh expect the formation of a community that is able to solve such problems. Such an agent can reprimand people who violate traffic signs, so that people feel embarrassed to do such action again.

\section{CONCLUSION}

The National Movement of the Mental Revolution mandated by President Joko Widodo in his state speech at the Regional Representative Council on 14 August 2015 has been well received by the Indonesian people, especially the people of Aceh. There is no other way to change the way of thinking, the way of view, the way of acting, mentality and character without the existence of a revolutionary way; therefore, the National Movement of the Mental Revolution is arguably an appropriate solution to overcome the nation's problems, concerning cleanliness, order, self-supporting, and unity.

\section{REFERENCES}

[1] A.W. Adam, Pelurusan Sejarah Indonesia, Yogyakarta: Penerbit Ombak, 2007.

[2] M. Bajovic, Rizzo, K., \& Engemann, J., "Character Education Reconceptualized for Practical Implementation", Canadian Journal of Educational Administration and Policy, no. 92, pp. 1-23, 2009.

[3] A. Budimanta, Buku Saku Seri 2: Panduan umum Gerakan Nasional Revolusi Mental, Jakarta: Sekretariat Revolusi Mental Kementerian Koordinator Bidang Pembangunan Manusia dan Kebudayaan, 2015.

[4] S.A. Kamaruddin, "Character Education and Students Social Behavior", Journal of Education and Learning, vol. 6, no. 4, pp. 223-230, 2015.

[5] W. Paulus, Jakarta: Sekretariat Revolusi Mental Kementerian Koordinator Bidang Pembangunan Manusia dan Kebudayaan, 2016.

[6] E.F. Rusydiyah, "Character Education through the Constructivist Design of Islamic Education Subject at Elementary School Pembangunan Jaya II in Gedangan Sidoarjo", Al-Ta Lim Journal, vol. 21, no. 3, pp. 227238, 2014.

[7] Winarno, Paradigma Baru Pendidikan Kewarganegaraan, Jakarta: Bumi Aksara, 2011. 